\title{
Merkezi Kompozit Dizayn Kullanılarak Kapesitabin Tayini için RPLC Yönteminin Geliştirilmesi ve Validasyonu
}

\author{
Yaşar Doğan DALDAL*1 (D, Ebru ÇUBUK DEMİRALAY2 ${ }^{\mathbb{D}}$ \\ 1Süleyman Demirel Üniversitesi, Fen Edebiyat Fakültesi, Kimya Bölümü, 32200, Isparta, Türkiye \\ 2Süleyman Demirel Üniversitesi, Eczacılık Fakültesi, Temel Eczacılık Bilimleri Bölümü, 32000, Isparta, Türkiye
}

(Alınış / Received: 27.06.2019, Kabul / Accepted: 23.10.2019, Online Yayınlanma/ Published Online: 20.04.2020)

Anahtar Kelimeler

Kapesitabin,

Rivastigmin,

Merkezi kompozit dizayn,

Metot validasyonu
Özet:Ters faz sıvı kromatografi (RPLC) yöntemi, merkezi kompozit dizayn (CCD) kullanılarak kapesitabinin analizi için geliştirilmiş ve valide edilmiştir. Metot üç faktörle (mobil faz organik modifiyer derişimi, mobil faz pH'sı ve kolon sıcaklığı) Minitab programı kullanılarak optimize edilmiștir. Optimum kromatografik koşullar, Derringer'in istenebilirlik fonksiyonu kullanılarak belirlenmiştir. CCD'nin yardımıyla tayin edilen ayırmanın optimum koşulları: (1) Mobil faz: asetonitril-su ikili karışımı oranı 40:60 (\%h/h), (2) kolon sıcaklığı $32^{\circ} \mathrm{C}$ ve mobil fazın pH'sı 7,5'dur. Çalışma, YMC triart C18 (150x4,6 mm I.D, $3 \mu \mathrm{m})$ kolonda ve $1 \mathrm{~mL} /$ dakika akıș hızında gerçekleștirilmiştir. Geliștirilen sıvı kromatografik yöntemin ICH parametrelerine göre validasyonu gerçekleștirilmiștir.

\section{Development and Validation of a RPLC Method for the Determination of Capecitabine using Central Composite Design}

\section{Keywords}

Capecitabine,

Rivastigmine,

Central composite design,

Method validation

\begin{abstract}
A reversed phase liquid chromatographic (RPLC) method was developed and validated for analysis of capecitabine using central composite design (CCD).The method was optimized using Minitab software with three factors (mobile phase organic modifier concentration, $\mathrm{pH}$ of the mobile phase and column temperature). The optimum chromatographic conditions were determined using Derringer's desirability function. The optimum conditions of separation (optimum values of significant factors) determined with the aid of CCD were: (1) mobile phase: The acetonitrile:water binary mixture ratio is 40:60 (\%, v/v), (2) column temperature $32^{\circ} \mathrm{C}$ and (3) $\mathrm{pH}$ of the mobile phase is 7.5. The study was carried out on a YMC triart C18(150x4.6 mm I.D, $3 \mu \mathrm{m})$ column and at a flow rate of 1 $\mathrm{mL} / \mathrm{min}$.The validation of the developed liquid chromatographic method according to ICH parameters was performed.
\end{abstract}

\section{Giriş}

Kanser hücre büyümesini ve gelişmesini sağlayan normal genlerin, regülasyon bozukluğu veya düzenleyici mekanizmalardan sapması ile ortaya çıkan bir hastalıktır. Kanserin ilaçla tedavisi kemoterapi olarak adlandırılır. Kanser, organizmada yer alan herhangi bir hücrenin farklılaşarak, aşırı ve kontrolsüz bir şekilde çoğalması sonucu oluşan hastalık olduğu için, neoplastik hastalıklar sınıfına girmektedir. Neoplastik hastalıkların tedavisinde, antineoplastik ilaçlar kullanılır. Antineoplastik ilaçlar, hücre bölünmesini ve dolayısıyla, çoğalmasını inhibe ederler fakat, kanser hücresine karşı olan selektiflikleri azdır. Kendi içerisinde 6 alt gruba ayrllan antineoplastikler içerisinde, antimetabolitler sık tercih edilen ilaçlardandır. Bu ilaçlar, DNA, RNA, proteinler ve diğer temel hücre bileşenlerinin sentez basamaklarında substrat veya koenzim olarak rol oynayan doğal metabolitlerin analoglarıdır [1-3]. Bir antimetabolit bileşik olan pirimidin antimetaboliti kapesitabin, kanser hücresinde pirimidin sentezini durdurur ve hücrede DNA sentezi için gerekli yapı taşlarından birinin eksilmesine yol açar (Şekil 1). Ayrıca bu bileșik,5- Fluorourasil'in analoğudur. Başta meme ve kolorektal kanser olmak üzere tümör dokusunun büyümesini de yavaşlatır $[3,4]$.

Ters faz sıvı kromatografi (RPLC) doğruluğu, kesinliği ve spesifikliği gibi birçok avantajlardan dolayı başta ilaç analizleri olmak üzere, birçok alanda tercih edilen bir yöntemdir. Bu yöntemde, farklı deneysel 
koşullara göre, seçilen sabit fazla analitin güçlü etkileşimi daha uzun alıkonmaya sebep olurken, sabit fazla analitin zayıf etkileşimi kısa alıkonma zamanına sebep olmaktadır [5]. RPLC metot geliștirmede, makul bir zamanda tayin edilen bileşiklerin yeterli ayrımı amaçlanmaktadır. Bu durumu sağlamak için, bileşiklerin alıkonma zamanı ( $\left.\mathrm{t}_{\mathrm{R}}\right)$ ve kapasite faktörü değerleri belli kurallara göre kontrol altına alınmaya çalışılır [6]. Bileşiklerin bu değerleri üzerine etkisi olduğu bilinen deneysel değişkenlerin optimize edilmesi bazı yaklaşımlarla gerçekleştirilebilir [5,7].

Genellikle, yapılan sıvı kromatografik çalışmalarda optimum ayırma koşullarını tayin etmek için, bileşiklerin $t_{R}$ değerleri üzerine etkisi olduğu bilinen parametrelerin incelenmesi temeline dayanan deneme-yanılma yaklaşımı tercih edilir. Ancak, bu yaklaşımın aşırı zaman kaybı ve maliyete sebep olması yanında, çalışılan bileşiklerin birbirinden ayrılmasını sağlayan sıvı kromatografik koşula ulaşılamaması gibi dezavantajları vardır. Bu gibi sorunları aşmak için, günümüzde, belirli bir istatistiksel temele dayanan, birden fazla parametrenin aynı anda incelenmesine imkân sağlayan daha sistematik yaklaşımlar olan deneysel tasarım metotlarının kullanımı giderek yaygınlaşmaktadır [8-10].

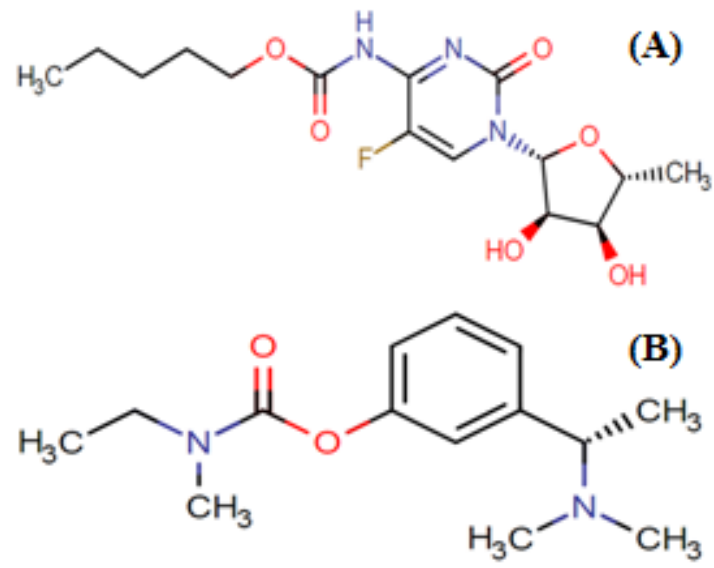

Şekil 1. Çalıșllan bileșiklerin kimyasal yapısı: Kapesitabin, (B) rivastigmin (I.S)

Deneysel tasarım metotlarından birisi olan merkezi kompozit dizayn (CCD), seçilen deneysel değişkenler ve bu değişkenlere karşı elde edilen cevap değerleri arasındaki ilişkiyi yorumlamak için çok kullanışlı bir yöntemdir [9]. CCD bu ilișkiyi seçilen deneysel değişkenlerle belirlenen bölge içerisinde, 2 . dereceden bir denklem ile ifade eder:

$$
y=\left(\begin{array}{c}
b_{o}+b_{1} x_{1}+b_{2} x_{2}+b_{3} x_{3} \\
+b_{12} x_{1} x_{2}+b_{13} x_{1} x_{3}+b_{23} x_{2} x_{3} \\
+b_{11} x_{1}^{2}+b_{22} x_{2}^{2}+b_{33} x_{3}^{2}
\end{array}\right)
$$

Eşitlik 1'de $b_{o}$ kesim değerini; $x_{1}, x_{2}, x_{3}$ seçilen değişkenlerin temel etkilerini; $x_{1} x_{2}, x_{1} x_{3}, x_{2} x_{3}$ seçilen değişkenlerin birbirleriyle etkileşimlerini; $x_{1}^{2}, x_{2}^{2}, x_{3}^{2}$ 'de eşitliğin star noktalarını ifade etmektedir $[11,12]$.
$\mathrm{Bu}$ denklem aracılı̆̆ıyla, seçilen deneysel değişkenlerin cevap olarak belirlenen değer üzerine etkisi olup olmadığı, varsa, ne düzeyde etkisi olduğu belirlenebildiğinden, CCD metodu sıvı kromatografik ayırmanın optimizasyon çalışmalarında çok tercih edilmektedir.

Pirimidin fonksiyonel grubu taşıyan antimetabolitlerden kapesitabin için gerçekleștirilen literatür taramasında, bileşiğin $\mathrm{pK}_{\mathrm{a}}$ tayini [13], kararlılık çalışmaları [14-16], biyolojik sıvılarda, dokularda ve tablet tayiniyle ilgili [17-21] çalışmalar bulunmuștur. Bileșiğin sıvı kromatografik tayini için deneysel tasarım metodu kullanılarak yöntem geliştirmeyle alakalı hiçbir çalışmaya rastlanmamıștır. Çalışmaların tamamında denemeyanılma kullanılmış, herhangi bir optimizasyon çalışmasına rastlanmamıştır. Bunun için, bu çalışmada CCD metodu kullanılarak, kapesitabin ve iç standart (I.S) olarak seçilen rivastigminin alıkonma davranışlarıyla, analitlerin alıkonmalarına en çok etkisi olduğu bilinen mobil faz organik modifiyer derişimi, mobil faz $\mathrm{pH}$ 'sı ve kolon sicaklığı parametreleri arasındaki ilişkinin belirlenip, mümkün olan en iyi sıvı kromatografik ayırma koşulunun belirlenmesi amaçlanmıştır. Ayrıca, bu çalışmada geliştirilen optimum ayırma koşullarının, ICH parametrelerine göre validasyonu gerçekleștirilmiş ve kapesitabinin insan idrarından geri kazanımına yönelik çalışmada gerçekleștirilmiştir.

\section{Materyal ve Metot}

\subsection{Kullanılan Kimyasal Maddeler}

Kapesitabin (analit), rivastigmin (I.S), urasil (kolonda tutunmayan bileşik) ve asetonitril (mobil fazda organik modifiyer) Sigma-Aldrich firmasından temin edilmiştir. Amonyum klorür ve amonyak (mobil fazda tampon bileşimi), potasyum hidrojen fitalat (elektrot kalibrasyonunda referans standart madde) Merck firmasından sağlanmıştır. Deneylerde kullanılan bütün kimyasal maddeler, analitik veya HPLC saflıktadır.

\subsection{Kullanılan Cihazlar}

Çalışılan bileşiklerin sıvı kromatografik davranışlarının incelenmesinde, Shimadzu marka yüksek performanslı sıvı kromatografi cihazı kullanılmıştır. Sistemde, pompa (LC-20AD), UV-Visible dedektör (SPD-20A), kolon firını (CTO-20A) ve gaz giderme ünitesi (DGU-20A3) bulunmaktadır. HPLC mobil fazının pH ölçümlerinde, Mettler Toledo MA 235 pH/ iyon analiz cihazı ve Mettler Toledo InLab 413 $\mathrm{Ag} / \mathrm{AgCl}$ kombine cam elektrot kullanılmıștır. IUPAC' In tavsiye ettiği gibi, asetonitril-su ikili karışımlarında elektrot kalibrasyonu için potasyum hidrojen fitalat, referans standart madde olarak seçilmiştir. Mobil faz $\mathrm{pH}$ 'sının ayarlanması esnasında, sıcaklık $25^{\circ} \mathrm{C} \pm$ $0,1^{\circ} \mathrm{C}^{\prime} \mathrm{de}$ sabit tutulmuştur.Deneysel çalışmalarda 
kullanılan ultra saf su Millipore Direct Q3-UV (Merck) saflaştırma sistemiyle elde edilmiştir. Tüm RPLC çalışmalar, YMC Triart C18 kolonda (150 mm X 4,6 $\mathrm{mm}, 3 \mu \mathrm{m})$ gerçekleştirilmiştir.

\subsection{Yöntem}

Çalışmada CCD ile belirlenen hacimce \% 24,887, \% $30, \% 37,5, \% 45$ ve \% 50,113 asetonitril içeren asetonitril-su ikili karışımı mobil fazlar hazırlanmıştır. pH 6,477-11,523 aralığında hazırlanan her bir mobil faza $30 \mathrm{mM}$ derișimde olacak şekilde katı $\mathrm{NH}_{4} \mathrm{Cl}$ ilave edilmiştir. Bu ortama su-asetonitril oranını bozmayacak şekilde derişik amonyak ilave edilerek, mobil fazın pH'sı çalışmada etkisi incelenmek istenen $\mathrm{pH}$ değerlerine getirilmiştir. Mobil fazlar ultrasonik karıștırıcıda degaze edildikten sonra kullanılmıştır. Çalışılan her bir mobil fazda kapesitabin ve rivastigmin (I.S)'in $t_{R}$ değerleri üç tekrarlı enjeksiyonların ortalaması olarak kullanılmıştır. Çalışılan bileşiklerin kapasite faktörü (k) değerlerinin hesaplanabilmesi için gerekli $t_{o}$ değerleri, urasil çözeltisinin 3 tekrarlı enjeksiyonlarının ortalaması olarak kullanılmıştır. Çalışma boyunca akış hızı, $1 \mathrm{~mL} /$ dakika'da sabit tutulmuştur. Kapesitabin ve rivastigmin (I.S) tayini için UV dedektör sırasıyla 240 ve 210 nm'ye ayarlanmıştır.

\section{4. Çalışılan bileşiklerin çözeltileri}

Kromatografik çalışmada kapesitabin $200 \mu \mathrm{g} / \mathrm{mL}$ ve rivastigmin $50 \mu \mathrm{g} / \mathrm{mL}$ olacak şekilde mobil fazda çözülerek hazırlanmıştır. Sonrasında kapesitabin için $50 \mu \mathrm{g} / \mathrm{mL}$ olacak şekilde ara stok hazırlanmıștır. Sıvı kromatografi cihazına analitler $20 \mu \mathrm{L}$ enjekte edilmiştir. Hazırlanan çözeltiler, günlük hazırlanmış ve $+4^{\circ} \mathrm{C}$ 'de muhafaza edilmiştir.

\section{5. İdrar numune çalıșması}

Sağlıklı bir insandan alınmış idrar numunesi 1:20 oranında seyreltilmiştir. Seyreltilmiş idrardan $2 \mathrm{~mL}$ alınmış, üzerine $3 \mathrm{~mL}$ asetonitril eklenerek numune içerisindeki proteinler çöktürülmüştür. Böylelikle proteinlerin bozucu etki oluşturması önlenmiştir. Bu 5 mL'lik idrar üzerine kapesitabinin farklı derişimleri, rivastigminden (I.S) 2,5 ppm'de sabit kalacak şekilde çözeltiye eklenerek karışım 10 mL'ye tamamlanmıştır. Bu 10 mL'lik karışım 0,45 $\mu$ m'lik filtreden geçirilmiştir. Filtreden geçirilen çözelti yüksek performanslı sıvı kromatografi cihazına enjekte edilmiştir.

\section{Bulgular}

\subsection{Kapesitabin ve rivastigmin için RPLC ayırmasının optimizasyonu}

Çalışılan bileşiklerin optimum ayırma koşullarını tayin etmek için, CCD metodu ile seçilen bağımsız parametrelerin sınırlarının belirlenmesine gerek duyulur. Bu nedenle, ilk olarak deneysel değişkenler olarak seçilen parametrelerin, alt ve üst seviyelerinin belirlenmesi gereklidir. $\mathrm{Bu}$ çalışmada, bileşiklerin $\mathrm{k}$ değerlerine etkisi olduğu bilinen mobil fazdaki asetonitril derişimi, pH'sı ve kolon sıcaklığı çalışılacak parametreler olarak seçilmiştir. Bu parametrelerin çalışma aralığı belirlenirken, kapesitabin ( $\left.\mathrm{pK}_{\mathrm{a}}: 9,360\right)$ [22] ve rivastigminin (pKa:9,019) (I.S) [23] protonasyon sabitlerinden $(\mathrm{pK}$ ) ve az sayıda ön denemeden yararlanılmıştır. Parametre seviyelerinin seçiminde, k değerlerinin 0,5 ile 5 aralığında olması; mobil faz pH'larının bileşiklerin iyonik ve moleküler formlarının olduğu pH değerlerini içermesi amaçlanmıştır. Kolon sıcaklığı parametresinin seviyelerinin de vücut sıcaklığı olan $37^{\circ} \mathrm{C}$ yi içine alması amaçlanmıştır (Tablo 1).

Tablo 1. Çalışılan bileşikler için seçilen parametrelerin alt, orta, üst ve alfa $(\alpha)$ seviyeleri

\begin{tabular}{|c|c|c|c|c|c|}
\hline $\begin{array}{l}\text { Bağımsız } \\
\text { parametreler }\end{array}$ & $(-\alpha)$ & $\begin{array}{c}\text { Alt } \\
\text { nokta } \\
(-)\end{array}$ & $\begin{array}{c}\text { Orta } \\
\text { nokta } \\
(0)\end{array}$ & $\begin{array}{c}\text { Üst } \\
\text { nokta } \\
(+)\end{array}$ & $(+\alpha)$ \\
\hline $\begin{array}{c}\left(\mathrm{x}_{1}\right) \\
\text { asetonitril } \\
(\%, \mathrm{~h} / \mathrm{h})\end{array}$ & 24,887 & 30,000 & 37,500 & 45,000 & 50,113 \\
\hline $\begin{array}{c}\left(\mathrm{x}_{2}\right) \text { mobil faz } \\
\mathrm{pH} \text { 'sl }\end{array}$ & 6,477 & 7,500 & 9,000 & 10,500 & 11,523 \\
\hline $\begin{array}{c}\left(\mathrm{x}_{3}\right) \text { sicaklık } \\
\left({ }^{\circ} \mathrm{C}\right)\end{array}$ & 31,591 & 35,000 & 40,000 & 45,000 & 48,409 \\
\hline
\end{tabular}

Seçilen üç bağımsız parametre için oluşturulan merkezi kompozit dizayn, merkez noktasında yapılan 6 tekrarla birlikte toplamda 20 farklı deney gerektirmektedir. Merkezi kompozit dizaynda çalışılan bu her koşulda kapesitabin ve rivastigminin alıkonma zamanı değerlerinden bileşiklerin $\mathrm{k}$ değerleri hesaplanmıştır. Bu k değerlerini kullanarak, bileşikler için deneysel tasarımda cevap değerleri olarak belirlenen logk ve seçicilik değerleri $(\alpha)$ hesaplanmıștır. (Tablo 2).

Tablo 2'de merkezi kompozit tasarımda belirlenen deney koşulları, incelenecek parametrelerin ana etkilerine ve parametrelerin birbirleriyle etkileşimlerine göre elde edilen logk ve $\alpha$ değerlerini göstermektedir. $\mathrm{Bu}$ deneylerin sonuçlarından hangi parametrenin ve/veya parametre etkileşimlerinin cevap olarak seçilen değerlere etkisinin olup olmadığını yada varsa ne ölçüde etkilediğini belirlemek için elde edilen tüm cevap değerlerine göre MINITAB 17 programıla çoklu regresyon analizi yapılmıștır. Bunun sonucunda, logk ve $\alpha$ değerine göre elde edilen eşitlikler, parametre veya etkileşimlerin önemini belirten $\mathrm{p}$ değerleriyle birlikte Tablo 3'de verilmiştir.

ANOVA tablosunda 0,05'den küçük p-değeri, \% 95 güven seviyesinde, ait olduğu katsayının cevap değerine etkisinin önemli olduğunu ifade etmektedir. Ayrıca, ANOVA tablosundaki model uygunsuzluğu (lack of fit, LOF), CCD ile geliştirilen matematiksel modelin cevap olarak belirlenen değerleri tahmin edebilme yetisindeki hatayı ifade etmektedir. Ĕger, 
LOF değeri 0,05'den büyükse, matematiksel modelin cevap değerlerini tahmin edebilme yetisindeki hata önemsizdir.

Tablo 2. Kodlanmış parametre seviyeleri ve bu seviyelerde elde edilen logk ve $\alpha$ değerleri

\begin{tabular}{|c|c|c|c|c|c|c|}
\hline \multirow[b]{2}{*}{ Dny.No } & \multirow[b]{2}{*}{$x_{1}$} & \multirow[b]{2}{*}{$x_{2}$} & \multirow[b]{2}{*}{$x_{3}$} & \multicolumn{2}{|c|}{$\operatorname{logk}$} & \multirow{2}{*}{$\begin{array}{c}\alpha(\text { seçicilik) } \\
\alpha \text { Rivastigmin/ } \\
\text { Kapesitabin }\end{array}$} \\
\hline & & & & Kapesitabin & Rivastigmin & \\
\hline 1 & - & - & - & 0,472 & 0,673 & 1,587 \\
\hline 2 & + & - & - & $-0,133$ & 0,312 & 2,790 \\
\hline 3 & - & + & - & $-0,245$ & 1,180 & 26,612 \\
\hline 4 & + & + & - & $-0,563$ & 0,601 & 14,565 \\
\hline 5 & - & - & + & 0,421 & 0,603 & 1,519 \\
\hline 6 & + & - & + & $-0,200$ & 0,250 & 2,824 \\
\hline 7 & - & + & + & $-0,184$ & 1,166 & 22,434 \\
\hline 8 & + & + & + & $-0,618$ & 0,591 & 16,186 \\
\hline 9 & $-\alpha$ & 0 & 0 & 0,492 & 1,204 & 5,144 \\
\hline 10 & $+\alpha$ & 0 & 0 & $-0,317$ & 0,404 & 5,266 \\
\hline 11 & 0 & $-\alpha$ & 0 & 0,137 & 0,111 & 0,943 \\
\hline 12 & 0 & $+\alpha$ & 0 & $-0,779$ & 0,824 & 40,064 \\
\hline 13 & 0 & 0 & $-\alpha$ & 0,037 & 0,790 & 5,657 \\
\hline 14 & 0 & 0 & $+\alpha$ & $-0,036$ & 0,736 & 5,910 \\
\hline 15 & 0 & 0 & 0 & 0,023 & 0,763 & 5,503 \\
\hline 16 & 0 & 0 & 0 & 0,011 & 0,763 & 5,657 \\
\hline 17 & 0 & 0 & 0 & 0,018 & 0,765 & 5,583 \\
\hline 18 & 0 & 0 & 0 & 0,023 & 0,765 & 5,520 \\
\hline 19 & 0 & 0 & 0 & 0,024 & 0,765 & 4,974 \\
\hline 20 & 0 & 0 & 0 & 0,021 & 0,773 & 5,642 \\
\hline
\end{tabular}

Tablo 3'de kapesitabin ve rivastigminin logk değerleri için verilen regresyon sonuçlarına göre; parametrelerin ana etkilerinden, kapesitabin için sıcaklığın önemsiz olduğu; rivastigmin için üç parametreninde önemli olduğu görülmektedir. Ayrıca, parametrelerin ana etkilerinin yanında, birbirleriyle ikili etkileșimleri de incelendiğinde kapesitabin için $\mathrm{ACN}^{*} \mathrm{ACN} ; \mathrm{ACN}^{*} \mathrm{t}^{\circ} \mathrm{C}$ ve $\mathrm{pH}^{*} \mathrm{t}^{\circ} \mathrm{C}$ değerlerinin önemsiz, diğerlerinin önemli olduğu görülmektedir. Rivastigmin için bu ikili etkileşimlerden $\mathrm{t}^{\circ} \mathrm{C}^{*} \mathrm{t}^{\circ} \mathrm{C}$ ve $\mathrm{ACN}^{*} \mathrm{t}^{\circ} \mathrm{C}$ değerlerinin önemsiz, diğer etkilerin ise önemli olduğu görülmektedir.

Parametrelerin iki bileşiğin seçicilik $(\alpha)$ cevap değerleri üzerine etkilerinin belirlenmesi için yapılan regresyon analizine göre, mobil faz pH'sının ve $\mathrm{pH}^{*} \mathrm{pH}$ veACN*pH ikili etkileşimlerinin önemli; diğer ana etkilerin (ACN ve $\mathrm{t}^{\circ} \mathrm{C}$ ) ve ikili etkileşimlerin önemsiz olduğu görülmektedir.

Yapılan regresyon analizi sonuçlarının parametrelerin her iki cevap değeri üzerindeki etkisini değerlendirerek, optimum ayırma koşulunu yorumlamadaki zorluklar nedeniyle, istenebilirlik fonksiyonundan faydalanılmıștır. Bu fonksiyonda, ilk başta her bir cevap değeri için istenen hedefler belirlenmiştir (Tablo 4).

Kapesitabin için hedef logk değeri 0,079 olarak, bileşiğin kapasite faktörü değerini 1,2 yapan $\mathrm{k}$ değerinden belirlenmiştir. Rivastigmin için logk değeri 0,380 olarak, kapesitabin piki ile rivastigmin pikinin arasındaki $\alpha$ değerini 1,15 yapan $\mathrm{k}$ değerinden belirlenmiştir. Daha sonra bu hedefler doğrultusunda, tasarımdaki tüm noktalar istenebilirlik skalasındaki 0 ile 1 arasındaki değerlere dönüștürülmüştür (Tablo 5). İstenebilirlik skalasına çevrilen değerler $\left(d_{\text {logk }}\right.$ ve $\left.d_{\alpha_{2-1}}\right)$, geometrik ortalama formülü kullanılarak tek bir cevap değerine dönüştürülmüştür.

$$
D=\left(d_{1}^{w_{1}} x d_{2}^{w_{2}} x \ldots d_{n}^{w_{n}}\right)^{1 /\left(w_{1}+w_{2+\ldots} w_{n}\right)}
$$

Eşitlik 2'de, $d_{i}$ değeri her deneyin cevap değerinin istenebilirlik fonksiyonuna dönüștürülmüș halini; $w_{i}$ cevapların ağırlıklarını; $n$ cevap sayısını ifade etmektedir.

Tablo 5'deki $D_{\text {hepsi }}$ değerlerini kullanarak, ayırmanın en iyi olduğu optimum ayırma koşulları, 3D yüzey yanıt diagramlarına göre belirlenmiştir (Şekil 2). Şekil 2'de verilen 3D yüzey diyagramlarıda dikkate alınarak yapılan değerlendirme neticesinde, optimum RPLC ayırma koşulları, 40 (\%v/v) asetonitril-su ikili karışımı, mobil faz pH' sı 7,5 ve kolon sıcaklığı $32^{\circ} \mathrm{C}$ olarak belirlenmiștir. Belirlenen bu optimum ayırma koşullarında elde edilen kromatogram, Şekil 3'de verilmiştir. Optimum ayırma koşulunda hesaplanan sıvı kromatografik parametreler, Tablo 6'da verilmiştir.

Tablo 3. Çalıșllan bileșiklerin logk ve $\alpha$ değerleri için regresyon analizi sonuçları

\begin{tabular}{|c|c|c|c|c|c|c|}
\hline \multirow[t]{2}{*}{ Faktör etkileri } & $\begin{array}{c}\text { Katsayılar } \\
\text { kapesitabin }\end{array}$ & $\mathrm{p}$ & $\begin{array}{c}\text { Katsayılar } \\
\text { rivastigmin }\end{array}$ & $\mathrm{p}$ & $\begin{array}{c}\text { Katsayılar } \\
\text { Rivastigmin/Kapesitabin } \\
\end{array}$ & $\mathrm{p}$ \\
\hline & \multicolumn{4}{|c|}{$\log \mathrm{k}$} & \multicolumn{2}{|l|}{$\alpha$} \\
\hline sabit & 0,029 & 0,058 & 0,764 & 0,000 & 5,472 & 0,000 \\
\hline ACN & $-0,245$ & 0,000 & $-0,235$ & 0,000 & $-1,141$ & 0,071 \\
\hline $\mathrm{pH}$ & $-0,272$ & 0,000 & 0,212 & 0,000 & 10,022 & 0,000 \\
\hline to $\mathrm{C}$ & $-0,017$ & 0,081 & $-0,018$ & 0,000 & $-0,159$ & 0,785 \\
\hline $\mathrm{ACN}^{*} \mathrm{ACN}$ & 0,011 & 0,221 & 0,014 & 0,000 & $-0,042$ & 0,941 \\
\hline $\mathrm{pH}^{*} \mathrm{pH}$ & $-0,133$ & 0,000 & $-0,105$ & 0,000 & 5,367 & 0,000 \\
\hline to $C^{*}$ to $C$ & $-0,019$ & 0,050 & $-0,001$ & 0,603 & 0,163 & 0,773 \\
\hline $\mathrm{ACN}^{*} \mathrm{pH}$ & 0,060 & 0,000 & $-0,055$ & 0,000 & $-2,600$ & 0,005 \\
\hline $\mathrm{ACN}^{*} \mathrm{t}^{\circ} \mathrm{C}$ & $-0,016$ & 0,189 & 0,002 & 0,376 & 0,738 & 0,341 \\
\hline $\mathrm{pH}^{*} \mathrm{t}^{\circ} \mathrm{C}$ & 0,015 & 0,217 & 0,014 & 0,000 & $-0,315$ & 0,678 \\
\hline LOF & \multicolumn{2}{|c|}{0,073} & \multicolumn{2}{|c|}{0,661} & \multicolumn{2}{|l|}{0,050} \\
\hline
\end{tabular}


Tablo 4. Cevapların optimizasyonu için belirlenen kriterler

\begin{tabular}{lclcccc}
\hline Bileșik & Cevap & Amaç & Alt seviye & Üst seviye & Hedef & A ğırlık \\
\hline \multirow{2}{*}{ Kapesitabin } & $\log k$ & Hedef & $-0,779$ & 0,472 & 0,079 & 1 \\
Rivastigmin & $\alpha_{2,1}$ & Hedef & 0,943 & 40,064 & 1,150 & 1 \\
\hline
\end{tabular}

Tablo 5. Cevap değerlerinin istenebilirlik skalasına göre karşılıkları

\begin{tabular}{|c|c|c|c|c|c|c|c|}
\hline Dny No & $x_{1}$ & $x_{2}$ & $x_{3}$ & $\begin{array}{c}d_{\log k} \\
\text { kapesitabin }\end{array}$ & $\begin{array}{c}d_{\log k} \\
\text { rivastigmin }\end{array}$ & $\begin{array}{c}d_{\alpha_{2 / 1}} \\
\text { Rivastigmin/ kapesitabin }\end{array}$ & $D_{\text {hepsi }}$ \\
\hline 1 & - & - & - & 0,031 & 0,691 & 0,000 & 0,000 \\
\hline 2 & + & - & - & 0,801 & 0,613 & 0,989 & 0,786 \\
\hline 3 & - & + & - & 0,663 & 0,029 & 0,362 & 0,191 \\
\hline 4 & + & + & - & 0,268 & 0,790 & 0,592 & 0,500 \\
\hline 5 & - & - & + & 0,108 & 0,777 & 0,000 & 0,000 \\
\hline 6 & + & - & + & 0,686 & 0,428 & 0,943 & 0,652 \\
\hline 7 & - & + & + & 0,697 & 0,045 & 0,425 & 0,237 \\
\hline 8 & + & + & + & 0,225 & 0,798 & 0,579 & 0,470 \\
\hline 9 & $-\alpha$ & 0 & 0 & 0,048 & 0,006 & 0,841 & 0,062 \\
\hline 10 & $+\alpha$ & 0 & 0 & 0,503 & 0,914 & 0,939 & 0,756 \\
\hline 11 & 0 & $-\alpha$ & 0 & 0,917 & 0,000 & 0,930 & 0,000 \\
\hline 12 & 0 & $+\alpha$ & 0 & 0,000 & 0,495 & 0,066 & 0,000 \\
\hline 13 & 0 & 0 & $-\alpha$ & 0,917 & 0,535 & 0,869 & 0,753 \\
\hline 14 & 0 & 0 & $+\alpha$ & 0,849 & 0,614 & 0,882 & 0,772 \\
\hline 15 & 0 & 0 & 0 & 0,947 & 0,572 & 0,887 & 0,783 \\
\hline
\end{tabular}

$d_{\alpha_{2 / 1}}:$ Seçiciliğin istenebilirliği, $d_{\log k}: \operatorname{logk}$ değerinin istenebilirliği; $D_{\text {hepsi }}:$ tüm cevap değerlerinin toplam istenebilirliği.

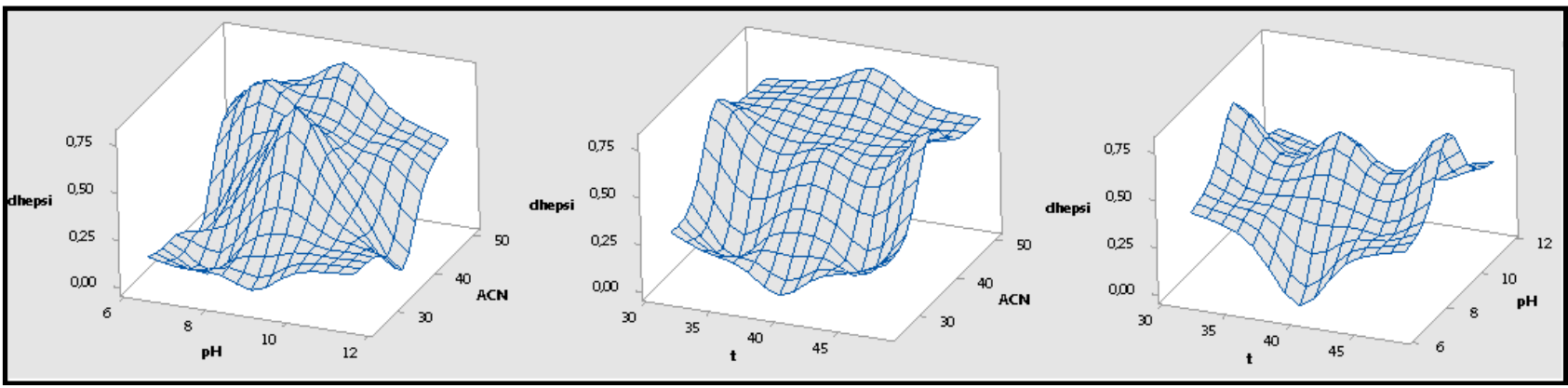

Şekil 2. Çalışılan bileşikler için çizilen 3D yüzey diyagramları

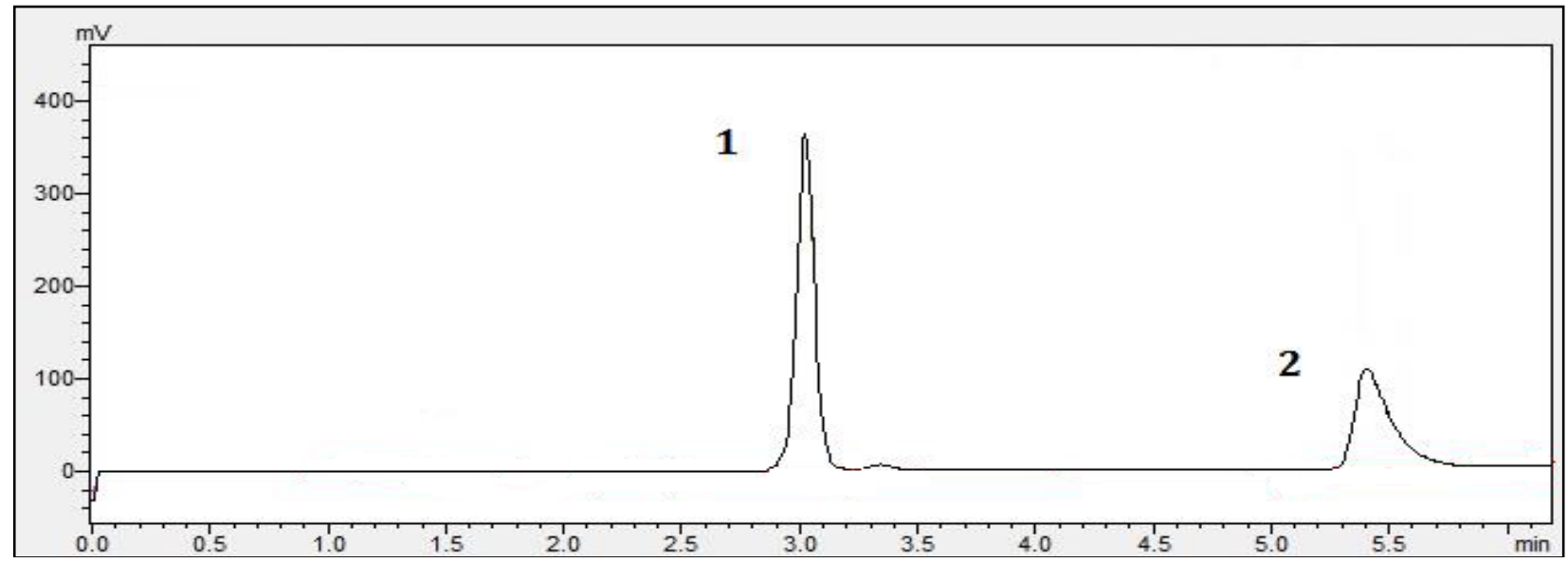

Şekil 3. Standart karışımın optimum koşulda elde edilen kromatogramı 1) kapesitabin(185 $\mu \mathrm{g} / \mathrm{mL}), 2)$ rivastigmin(I.S)(50 $\mu \mathrm{g} / \mathrm{mL})$

Tablo 6. Çalışılan bileşikler için optimum ayırma koşullarına göre elde edilen alıkonma zamanı, seçicilik ve ayırma gücü değerleri

\begin{tabular}{|c|c|c|c|c|c|c|c|}
\hline Bileşikler & $t_{R}$ & $k$ & $\alpha$ & $(a-1) / a$ & $k_{2} / k_{2}+1$ & $\left(\frac{1}{4}\right) \sqrt{N}$ & $R_{S}$ \\
\hline Kapesitabin & 3,021 & 1,105 & & & & & \\
\hline Rivastigmin & 5,400 & 2,763 & 2,500 & 0,600 & 0,734 & 18,971 & 8,358 \\
\hline $\operatorname{Urasil}\left(\mathrm{t}_{0}\right)$ & 1,435 & & & & & & \\
\hline
\end{tabular}




\subsection{Geliştirilen metodun validasyonu}

Geliştirilen yöntemin geçerliliğinin kanıtlanması amaciyla, ICH validasyon parametrelerine göre geliştirilen yöntem test edilmiştir. $\mathrm{Bu}$ amaçla, validasyon çalışmalarında; doğrusallık, duyarlılık, kesinlik, geri kazanım, tekrarlanabilirlik parametreleri incelenmiş ve istatiksel değerlendirmeleri yapılmıştır.

Çalışmada metot validasyonu çalışması için iç standart metodu uygulanmıştır. Bunun için rivastigmin iç standart olarak seçilmiştir. Rivastigmin kapesitabin gibi bazik fonksiyonel grup taşıyan bir bileşiktir. Belirlenen optimum ayırma koşullarında kapesitabinin alıkonma zamanına yakın bir değerde pik vermiş ve kapesitabinden ayrılmıştır. Bunun için rivastigmin iç standart olarak bu çalışmada tercih edilmiştir.

\subsubsection{Kalibrasyon doğrusu ve duyarlılık}

Kapesitabinin yüksek performans sıvı kromatografisi ile analizi yönteminde doğrusal aralığın belirlenmesi için 2 . bölümde anlatılan idrar numunesine $2 \mu \mathrm{g} / \mathrm{mL}$ ile $12 \mu \mathrm{g} / \mathrm{mL}$ aralığında farklı derişimlerde kapesitabin ve $2,5 \mu \mathrm{g} / \mathrm{mL}$ derișimde sabit tutulan iç standart rivastigmin eklenerek kalibrasyon çözeltileri hazırlanmıştır. Kalibrasyon doğrusu, kapesitabinin her bir derişim değeri için elde edilen pik alanının I.S'ın pik alanına oranının, kapesitabin derişimi değerine karşı işaretlenmesiyle oluşturulmuştur. Geliştirilen yöntem kapesitabiniçin $2 \mu \mathrm{g} / \mathrm{mL}$ ile 12 $\mu \mathrm{g} / \mathrm{mL}$ arasında doğrusal olduğu belirlenmiş̦tir. Kapesitabin analizi için hesaplanan kalibrasyon verileri, Tablo 7'de verilmiștir.

Tablo 7. Kapesitabinin analizine ait kalibrasyon fonksiyonu özellikleri

\begin{tabular}{cc}
\hline Regresyon Denklemi* $^{*}$ & $\mathrm{y}=0,539 \mathrm{x}-0,059$ \\
\hline Ĕgimin Standart Hatası & 0,010 \\
Kesimin Standart Hatası & 0,074 \\
Korelasyon Katsayısı $(\mathrm{r})$ & 0,999 \\
Kalibrasyon Aralığı $(\mu \mathrm{g} / \mathrm{mL})$ & $2,000-12,000$ \\
Teşhis Sınırı $(\mu \mathrm{g} / \mathrm{mL})$ & 0,490 \\
Tayin Alt Sınırı $(\mu \mathrm{g} / \mathrm{mL})$ & 1,484 \\
\hline *y $=$ bx $+\mathrm{a} ; \mathrm{x}: \mu \mathrm{g} / \mathrm{mL}$ biriminde derişim; $\mathrm{y}:$ Kapesitabin $/ \mathrm{I} . S$ alan \\
oranı değerleri
\end{tabular}

\subsubsection{Sistem uygunluk testi sonuçları}

Sistem uygunluk testleri (SST), geliștirilen RPLC yöntemin tekrarlanabilirliğini değerlendirmek için uygulanan testlerdir. $\mathrm{Bu}$ testler, tekrarlanan enjeksiyonlar için pik alanı ve $t_{R}$ değerlerinin bağıl standart sapması (\% BSS), seçicilik ( $\alpha$ ), kuyruklanma faktörü (TF), alıkonma zamanı $\left(t_{R}\right)$, teorik tabaka sayısı $(N)$, ayırma gücü $\left(R_{s}\right)$ ve kapasite faktörü $(k)$, parametrelerin değerlendirilmesinden oluşmaktadır. $\mathrm{Bu}$ test uygulamasında kapesitabin için $6 \mu \mathrm{g} / \mathrm{mL}$, rivastigmin için $2,5 \mu \mathrm{g} / \mathrm{mL}$ derişimlerde hazırlanan çözeltiler sisteme 5 tekrarlı olarak enjekte edilmiş ve verilerin ortalaması alınarak, kromatografik parametreler hesaplanmıștır. Elde edilen veriler, Tablo 8'de verilmiştir. Sistem kararlılık parametrelerine göre gerçekleştirilen değerlendirmede, geliştirilen RPLC yöntemin rutin analizler için uygun olduğu görülmektedir.

Tablo 8. Kapesitabin ve rivastigmin için sistem uygunluk parametreleri

\begin{tabular}{|c|c|c|c|}
\hline Param. & Kapesitabin & Rivastigmin (IS) & $\begin{array}{l}\text { Önerilen } \\
\text { değerler }\end{array}$ \\
\hline$t_{R}$ & 3,176 & 5,450 & \\
\hline $\mathrm{TF}$ & 1,023 & 1,217 & $0,95-1,20$ \\
\hline $\mathrm{k}$ & 2,710 & 3,837 & $>1$ \\
\hline $\mathrm{R}_{\mathrm{s}}$ & \multicolumn{2}{|c|}{11,507} & $>2$ \\
\hline $\mathrm{N}$ & 6605 & 12173 & $>2000$ \\
\hline$\alpha$ & \multicolumn{2}{|c|}{2,478} & $>1$ \\
\hline $\mathrm{RSD}\left(\mathrm{t}_{\mathrm{R}}\right)$ & 0,094 & 0,090 & $\leq 1$ \\
\hline RSD(alan) & 0,040 & 0,018 & $\leq 1$ \\
\hline
\end{tabular}

\subsubsection{Kesinlik sonuçları}

Kapesitabin tayini için kesinlik çalışmaları için gün içi ve günler arası testleri uygulanmıştır. Gün içi çalışmaları iki farklı derişim düzeyinde ve beş bağımsız çözelti kullanılarak aynı gün içerisinde; günler arası çalışmalar ise iki farklı derişim düzeyinde beș bağımsız çözelti kullanılarak üç ayrı günde yapılmıştır. Bu testler sonucunda elde edilmiş veriler, Tablo 9'da verilmiștir.

\subsubsection{Geri kazanım sonuçları}

Geliştirilen RPLC yönteminin doğruluğunu ve idrar numunesi içerisinde bulunan proteinlerin yönteme bir etkisinin olup olmadığını belirlemek için, kapesitabinin idrar numunesinden geri kazanım deneyleri gerçekleştirilmiştir. Normal şartlarda, sağlıklı bir insanda vücuda alınmadıkça, bu bileşikler bulunmaz. Kapesitabin ve rivastigminin bulunmadığ idrara ait kromatogram, Şekil 4'de verilmiștir.

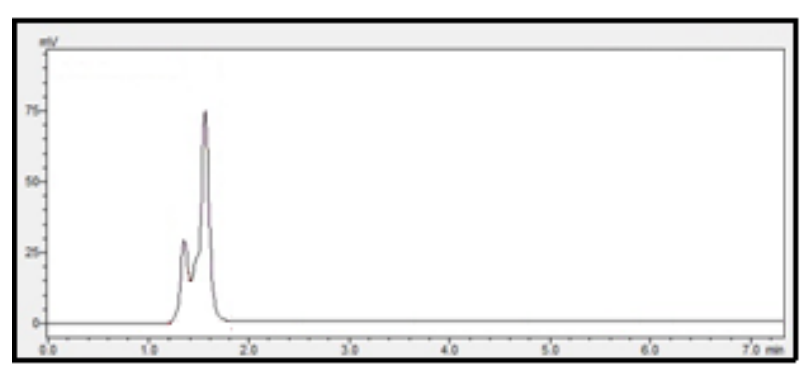

Şekil 4. Kapesitabin ve rivastigmin (I.S) bulunmayan idrar kromatogramı

$\mathrm{Bu}$ çalışmada, idrara kapesitabin çözeltisinden $4 \mu \mathrm{g} / \mathrm{mL}$ ve $8 \mu \mathrm{g} / \mathrm{mL}$;rivastigmin (I.S) çözeltisinden idrarda 2,5 $\mu \mathrm{g} / \mathrm{mL}$ derişimde olacak şekilde katkı yapılmıştır. Bu işlem birbirinden bağımsız 3 kez ayrı ayrı yapılmıştır. 
Tablo 9. Kapesitabinin analiz yöntemine ait gün içi ve günler arası kesinlik ve doğruluk analizi bulguları

\begin{tabular}{cccccc}
\hline & $\begin{array}{c}\text { Teorik Derişim } \\
(\mu \mathrm{g} / \mathrm{mL})\end{array}$ & $\begin{array}{c}\text { Gün içi derişim } \\
\text { ortalaması }\end{array}$ & $\begin{array}{c}\% \text { BSS } \\
(\mu \mathrm{g} / \mathrm{mL})\end{array}$ & $\begin{array}{c}\text { Günler arası } \\
\text { derişim ortalaması }\end{array}$ & $\begin{array}{c}\% \text { BSS } \\
(\mu \mathrm{g} / \mathrm{mL})\end{array}$ \\
\hline \multirow{3}{*}{ Kapesitabin } & 4 & 3,974 & 0,540 & 3,931 & 0,782 \\
& 10 & 10,077 & 0,080 & 9,957 & 0,280 \\
\hline
\end{tabular}

Tablo 10. İnsan idrarında kapesitabinin RPLC analizi için geri kazanım sonuçları

\begin{tabular}{|c|c|c|c|c|c|c|}
\hline Bileşik & $\begin{array}{c}\text { Teorik } \\
\text { Derişim } \\
(\mu \mathrm{g} / \mathrm{mL})\end{array}$ & $\mathrm{N}$ & $\begin{array}{c}\text { Ortalama bulunan derişim } \\
\text { (konsantrasyon ort. }(\mu \mathrm{g} / \mathrm{mL} \text { ) } \\
\pm \text { güven aralığ })\end{array}$ & $\begin{array}{c}\text { Geri kazanım (\%) } \\
\text { (yüzde ort. } \pm \text { güven aralığı) }\end{array}$ & SS & $\begin{array}{l}\text { BSS } \\
(\%)\end{array}$ \\
\hline \multirow{2}{*}{ Kapesitabin } & 4 & 3 & $3,971 \pm 0,013$ & $99,269 \pm 0,256$ & 0,103 & 0,731 \\
\hline & 8 & 3 & $8,094 \pm 0,012$ & $101,175 \pm 0,899$ & 0,050 & 0,124 \\
\hline
\end{tabular}

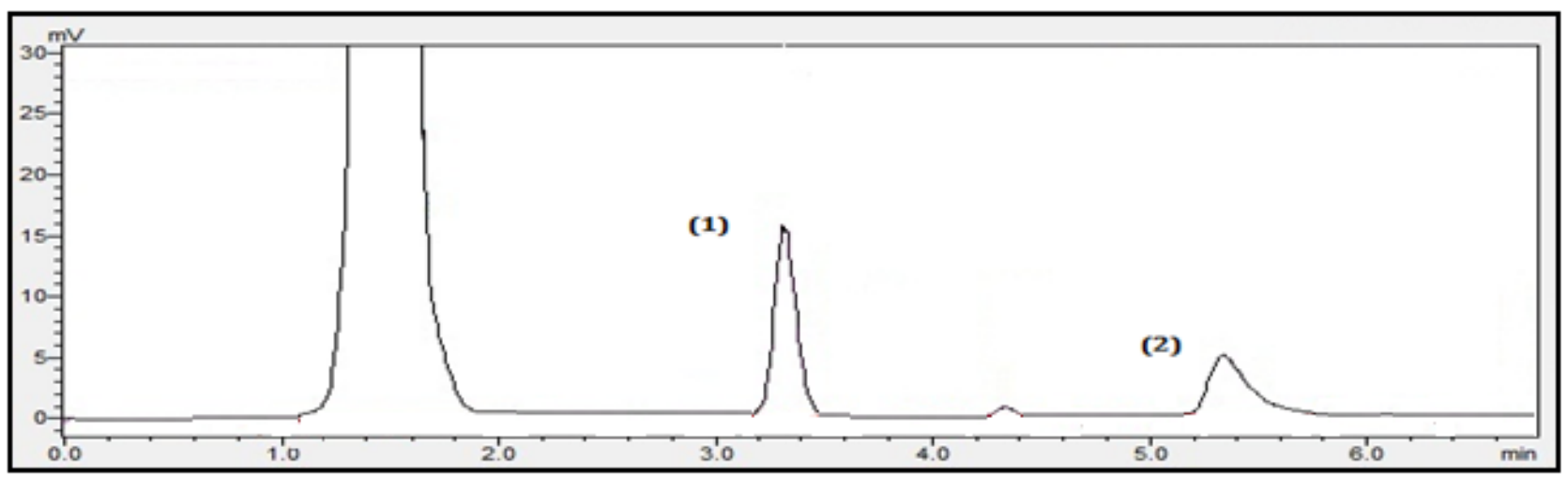

Şekil 5. Kapesitabin ve rivastigmin (I.S) ile katkılandırılmış idrar numunesi; 1) kapesitabin (8 $\mu \mathrm{g} / \mathrm{mL}$ ) 2) rivastigmin (I.S) (2,5 $\mu \mathrm{g} / \mathrm{mL})$

Yapılan analiz sonucunda okunan pik alan oranı değerleri kalibrasyon denkleminde yerine konularak, idrar numunelerinin içerdiği kapesitabin miktarı hesaplanmıştır. Elde edilen sonuçlar, Tablo 10'da verilmiștir. Kapesitabin ve rivastigmin (I.S) ile katkılandırılmıș idrar numunesinin analizi sonucu elde edilmiş kromatogram, Şekil 5'de verilmiștir.

\section{Tartışma ve Sonuç}

Bu çalışma, kapesitabinin RPLC yöntemiyle tayini için yapılan optimizasyon çalışmasında merkezi kompozit dizayn metodu kullanılarak gerçekleştirilen ilk çalışmadır. Farklı kromatografik davranışa sahip olan bileşiklerin, eş zamanlı kromatografik tayininde mümkün olan en iyi sıvı kromatografik ayırma koşulu, Derringer'in istenebilirlik fonksiyonuyla belirlenmiștir. Bu fonksiyon sayesinde CCD'den elde edilen veriler, 3D yüzey yanıt diyagramlarıyla değerlendirilerek tek bir ayırma koşuluna karar verilmiştir. Geliştirilen RPLC yöntemin ICH parametrelerine göre gerçekleştirilen çalışma verileri yöntemin rutin uygulamalar için uygun olduğunu göstermiştir.

\section{Teşekkür}

Bu çalışma, Süleyman Demirel Üniversitesi Bilimsel Araştırma Projeleri Yönetim Birimi Başkanlığı 4581D2-16 nolu proje ile desteklenmiștir. Çalışmamızı maddi olarak destekleyen Süleyman Demirel Üniversitesi Bilimsel Araştırma Projeleri Yönetim Birimi Başkanlığına teşekkür ederiz.

\section{Kaynakça}

[1] Tozkoparan, B., Aytaç, S.P., 2007. Kanser kemoterapisinde terapötik hedef olarak glutatyon s-transferazlar. Hacettepe Üniversitesi, Eczacıllk Fakültesi Dergisi, 27(2), 139-64.

[2] Domaç, M. (Ed.) 2005. Kemoterapötikler. Fersa Matbaacılık Ltd., Ankara,96s.

[3] Kayaalp, 0. 2000. Rasyonel Tedavi Yönünden Tıbbi Farmakoloji. Hacettepe-Taș Kitapçıllk Ltd. Ști, Ankara, 880s.

[4] Süzer, Ö. (Ed.) 2009. Goodman \& Gillman Tedavinin Farmakolojik Temeli. Nobel Tıp Kitabevi, Ankara, 2017s.

[5] Kazakevich, Y., Lobrutto, Y. 2007. HPLC for Pharmaceutical Scientists. Wiley-Interscience, Canada, USA, 1135s.

[6] ICH Expert Working Group, 2005, April. Validation of analytical procedures: text and methodology Q2 (R1). In Proceedings of the International Conference on Harmonisation of Technical Requirements for Registration of Pharmaceuticals for Human Use, Geneva, Switzerland.

[7] Meyer, V.R. 2010. Practical High-Performance Liquid Chromatography. John Wiley and Sons, Ltd., United Kingdom, 428s.

[8] Uysal, R., Daldal, Y.D., Üstün, Z., Çubuk Demiralay, E. 2017. Optimization of RPLC 
Method for Separation of Some Acetylcholinesterase Inhibitors by using Central Composite Design. Eurasian Journal of Analytical Chemistry, 12(1), 23-43.

[9] Gündoğan, B., Çubuk Demiralay, E., Daldal, Y.D., Üstün, Z. 2017. Determination of Optimum Separation Condition for Some Carbapenem Antibiotics Using RPLC with the Aid of Central Composite Design and Desirability Function. Current Pharmaceutical Analysis, 13,100-109.

[10] Çubuk Demiralay, E. 2012. An Experimental Design Ap proach to Optimization of the Liquid Chromatographic Separation Conditions for the Determination of Metformin and Glibenclamide in Pharmaceutical Formulation. Acta Chima Slovenica, 59(2), 307-314.

[11] Myers, R.H., Montgomery, D.C. 2002. Response Surface Methodology. Wiley, New York, 798s.

[12] Montgomery, D.C. 2005. Design and Analysis of Experiments. John Wiley \&Sons, Westford, 757s.

[13] Meloun, M., Zuzana Ferenčiková, Vrána, A. 2011. Determination of The Thermodynamic Dissociation Constant of Capecitabine Using Spectrophotometric and Potentiometric Titration Data.The Journal of Chemical Thermodynamics, 43, 930-937.

[14] Łaszcz,M., Trzcińska, K., Filip, K., Szyprowska, A., Mucha, M., Krzeczyński, P. 2011. Stability Studies of Capecitabine. Journal of Thermal Analysis and Calorimetry, 105, 1015-1021.

[15] Pujeri, S.S., Khader, A. M. A., Seetharamappa, J. 2012. Stability Study of CapecitabineActive Pharmaceutical Ingredient in Bulk Drug and PharmaceuticalFormulation. Journal of Liquid Chromatography \& Related Technologies, 35, 40-49.

[16] Wang, X.J, You, J.Z. 2016. Study on The Thermal Decomposition of Capecitabine. Journal of Thermal Analysis and Calorimetry, 123, 24852497.

[17] Farkouh, A., Ettlinger, D., Schueller, J., Georgopoulos, A., Scheithauer, W., Czejka, M.
2010. A Rapid and Simple HPLC Assay for Quantification ofCapecitabine for Drug Monitoring Purposes. Anticancer Research,30, 5207-5212.

[18] Deenen, M.J., Rosing, H., Hillebrand, M.J., Schellens, J.H.M., Beijnen, J. H. 2013. Quantitative Determination of Capecitabine and İts Six Metabolites in HumanPlasma Using Liquid Chromatography Coupled to Electrospray Tandem MassSpectrometry. Journal of Chromatography B, 913, 30-40.

[19] Deng, P., Ji, C., Daia, X., Zhong, D., Ding, L., Chen, X. 2015. Simultaneous Determination of Capecitabine and its Three Nucleosidemetabolites in Human Plasma by High Performance Liquid ChromatographyTandem Mass Spectrometry. Journal of Chromatography B, 989, 71-79.

[20] Jacobs, B. A.W., Rosing, H., de Vries, N., Meulendijks, D., Henricks, L. M., Schellens, J.H.M., Beijnen, J.H. 2016. Development and Validation Of A Rapid and Sensitive UPLC-MS/MS Method for Determination of Uracil and Dihydrouracil in Human Plasma. Journal of Pharmaceutical and Biomedical Analysis, 126, 75-82.

[21] Stashkevich, M.A., Khomutov, E.V., Dumanskii, Y.V.,Matvienko, A.G., Zinkovich, I.I. 2016. Effect of 5-Fluorouracil on Thymidine Phosphorylasectivity in Model Experiment. Bulletin of Experimental Biology and Medicine, 160(5),646-647.

[22] Daldal, Y.D. 2018. Kemoterapide kullanılan bazı antimetabolit ilaçların sivı kromatografik tayininde merkezi kompozit dizayn tekniğinin uygulanması. Süleyman Demirel Üniversitesi, Fen Bilimleri Enstitüsü, Doktora Tezi, 233s, Isparta.

[23] Daldal, Y.D., Demiralay, E.Ç., Ozkan, S.A. 2016. Effect of Organic Solvent Composition on Dissociation Constants of Some Reversible Acetylcholinesterase Inhibitors, Journal of the Brazilian Chemical Society, 27(3), 493-499. 